\title{
School Partnership Management in Improving Vocational School Education Quality with Teaching Factory in Tabalong District, South Kalimantan Prov- ince
}

\author{
Yuli Rinawati *, Ahmad Suriansyah, Ngadimun \\ Master Program of Education Management, Universitas Lambung Mangkurat, Banjarmasin 70123, \\ Indonesia
}

\author{
Article history: \\ Submission December 2020 \\ Revised March 2021 \\ Accepted March 2021 \\ ${ }^{*}$ Corresponding author: \\ E-mail: \\ yulirinawati@yahoo.com
}

\begin{abstract}
This research arises from the importance of vocational schools' existence through efforts preparing students to become workers ready. This is aimed at reducing unemployment and improving the economy in Indonesia. School partnership management is an effort to align the learning process with the needs of the workforce in the industrial and business world. This research focused on how to plan, organize, implement, and evaluate school partnerships in improving the quality of education with Teaching Factory at SMKN 1 Tanjung and SMKN Murung Pudak in Tabalong Regency, South Kalimantan Province. This research uses a qualitative descriptive approach with a multisite research design. This research conducts three data collection techniques, namely: (1) in-depth interviews, (2) observation, and (3) Documentation and multi-site research. The subjects of this study are the principals, all parts of the vice principals, teachers, educators, and students in SMKN 1 Tanjung and SMKN Murung Pudak Tabalong. The research was analyzed using an interactive data analysis model from Humberman and Miles, with the following stages: data collection, data collection, drawing conclusions, and checking the validity of the findings with credibility, dependability, and confirmability. The collected data is analyzed with a single site, followed by cross-site analysis. The research shows that the relationship of partnership schools in increasing the quality of education at SMKN 1 Tanjung and SMKN Murung Pudak Tabalong has done a partnership school with the business or industry in several ways: based through the vision of the school's mission, goal-setting partnership, programming work, schools actively communicate with the world of work, the synchronization of curriculum, teacher education, and training, internship in the industry, guest teachers from school partners, equalization of facilities and infrastructure, and the school's efforts to convince school partners. Industrial practice is done as if it were in the real world of work so that it is following the Teaching Factory program.
\end{abstract}

Keywords: Partnership management, increasing education quality

How to cite:

Rinawati, Y. (2021). School partnership management in improving vocational school education quality with teaching factory in Tabalong District, South Kalimantan Province. Journal of K6 Education and Management, 4 (1), 37 -50. doi: 10.11594/jk6em.04.01.04 


\section{Introduction}

Education development is entering the era of globalization which is marked by incessant technological innovation so that the education system needs an adjustment in harmony with the world of work. Educational actors in preparing these resources cannot be ignored. The education program prepared must be oriented to the needs of the job market (OECD, 2017). Vocational high school (SMK) is a school that provides provisions for students to study various knowledge and technology, which is oriented towards religious education with a vocational program in its curriculum. The special purpose of SMK is to prepare students with the knowledge, competence, technology, and art to become productive, independent people, to fill job vacancies in the business world and industry as middle-level workers according to competence (Shrestha, 2016). The ability of vocational skills that are oriented towards the readiness of the younger generation who can directly enter the workforce (Greenbank, 2014), after graduating from SMK.

The reality is that the human resources for SMK graduates are still underestimated (Hippach-Schneider et al., 2017) in Indonesia. Many vocational graduates are unemployed, even in areas where there are a lot of industries. To fulfill the school's service to students, the school tries to establish school partnerships (Sanders et al., 2005). It aims to create and develop school programs to be more successful in serving the students and improve the quality of graduates who have two skills, both hard skills and soft skills.

The school partnership with the business actors is a continuous effort to achieve common goals (Sandika \& Usman, 2017) by dividing authority and responsibility and dividing between responsibility and authority, and as a supporter but cooperation in the sense of partnership (Elgar, 2012).

Based on this fact, this research is interested in examining in depth the importance of partnerships built by schools to improve the quality of education at SMKN 1 Tanjung, Tabalong district which was founded in 1970, is a school that initially only had five departments, namely Computer engineering, Multimedia, Accounting, Office Administration, and Marketing. While SMKN 1 Murung Pudak was founded in 2011 with majors in Nursing, TKR, Hospitality, Pharmacy, TKJ, and OTTKP.

\section{Material and Methods \\ Time and place}

This research was conducted from February 14,2020 , to July 27,2020 . The object of research was conducted at SMKN 1 Tanjung and SMKN 1 Murung Pudak in Tabalong district, South Kalimantan province.

\section{Data type}

This type of research is multi-site research. The research approach used is a qualitative descriptive research approach (Denzin \& Lincoln, 2011), namely the conclusion. This study aims to obtain an overview related to the management of partnerships between schools and partners to produce quality education (Simons et al., 2013). Researchers are required to go into the field to study intensively the background, current state, and environmental interactions of a social unit, individual, group, institution, or community. This will give the meaning that the researcher immediately executes what is the focus of the research and according to the location that has been selected and puts it in descriptive form. Multi-site ( Audet \& d'Amboise, 2001) is a study conducted in different locations to get something different from each research location by comparing research findings by comparing the findings of researchers from two research sites.

\section{Research attendance}

The qualitative human approach has a major role in data mining (Rashid et al., 2017). Humans are the main instrument in research. The important thing that must be done, research does not only focus on IQ (Intellectual Quotient) to obtain data but needs to be added with EQ (Emotional Quotient), which is the ability to do emotionally, politely, ethically. Researchers make direct observations 
into the field to find as much data as possible that has something to do with the research focus. Data that is not obtained through observation and documents will be explored through interviews. In extracting data, the researcher will interview informants or respondents who are considered capable of providing accurate information that has something to do with the research focus and what the researcher needs to make a research report.

\section{Research setting}

This research is a multi-site research carried out at SMKN 1 Tanjung and SMKN Murung Pudak. The author's reason for this research was conducted at SMKN Tanjung and SMKN Murung Pudak because both have a school partnership relationship with the same party.

\section{Data source}

According to Arikunto (1992), to search for data, the source of the data must first be determined. Data sources are an important part of the research. Sources of data are obtained from the information obtained by researchers (Baral, 2017) in the form of data needed by researchers. While the sources used in this study are divided into two sources, namely human data sources and data sources in the form of relevant documents, hard data, pictures, photos, notes that are closely related to the focus of the study. Data obtained from humans, namely people who are considered to know the problem according to the data expected by the researcher. The data collected in this research is in the form of information in the form of words and documents the form of words and documents.

The data sources in this study are divided into two, namely:

\section{Primary data source}

The things that become the primary data source Ajayi (2017), namely; a) Informants, such as school principals, vice-principals in the Curriculum Division, educators, and coordinators of parties that partner with schools.

b) For research purposes, selected from among those who are thought to have or have had a close relationship with the problem being researched.

\section{Secondary data source}

Secondary data sources Ajayi (2017) are complementary data sources from primary data sources obtained in the form of data needed by researchers in the form of archives, official documents, books, papers, and author's documents. This document is needed as a researcher needs to complete the writing of this qualitative research.

Concerning data from humans or key informants, researchers involved principals of SMKN 1 Tanjung and SMKN Murung Pudak, deputy head of the student division, deputy head of infrastructure, deputy head of the curriculum, department heads, and staff of SMKN 1 Tanjung and SMKN Murung Pudak. The selection of student staff, infrastructure staff, curriculum staff, department heads, and staff, as informants, because; first, they are actors who are directly involved in every activity related to the curriculum, student development, infrastructure, and departments that are directly related to the parties partnering with the school. Second, they know firsthand about the problems in the fields of students, curriculum, infrastructure, and departments related to the partners. Third, they know more about events, any needs that have to do with their respective fields.

\section{Research instrument}

The main research instrument in qualitative research is the researcher himself, conducting data collection, assessing data quality, analyzing data, interpreting data, and making conclusions on the findings. 


\section{Techniques and data collection procedures}

Data collection techniques in this study using research instruments commonly used for qualitative research are as follows:

\section{Participant observations}

In observation, researchers use books for notes and recording devices. Notes are used to record important things during observation. A recording device is used to capture moments that are relevant to the focus of the research.

Observation according to Moleong (2002) is a way to collect the desired information by making direct observations. The observation method is to explore data Kawulich (2005) related to school partnership management in improving the quality of education at SMKN 1 Tanjung and SMKN Murung Pudak in Tabalong district.

The observation is needed to be able to understand the process of the interview, where the results of the interview can be understood in context. Observations were made on subjects and things that were considered relevant so that they could provide additional data from the results of the interviews to complete the data needed by the researcher (Qaddo, 2019). This observation was carried out by the researcher in three stages, namely (1) descriptive observation, to know the general picture before the research was carried out (2) focused observation in which the aim was to find the categories of data that were explored, (3) selective observation, to find differences between categories of data obtained. This study uses direct observation techniques, where to explore the data that will be sought, the researcher comes directly to the location of the two schools where the researcher is carrying out research that is in the research focus.

Researchers made observations at the locations of SMKN 1 Tanjung and SMKN Murung Pudak in Tabalong Regency.

\section{Interview}

According to Mantja (2008), interviews are focused conversations to seek more detailed information or data where the results are used for analysis. interview which is often called an interview or an oral questionnaire is a dialogue conducted by the interviewer (interviewer), namely the researcher himself.

\section{Documentation}

According to Satori \& Komariah, (2009), a documentary study is a process of collecting documents and data needed in a researcher's problem, then being observed intensely so that it can support and increase confidence and prove an incident.

To complement the data obtained from observations and interviews, researchers used documentation. Documents are used as a way to obtain valid data, and to strengthen data from previous observations. Documentation in the form of notes, transcripts, organizational structure, brochures, photos, activity agenda books, and many more have to do with the data needed by the author which is closely related to the research focus (Mogalakwe, 2006).

\section{Data analysis procedure}

Data analysis is the process of reviewing and systematically arranging all interview transcripts, field notes, materials, or data that the researcher wrote during data collection (Bogdan \& Biklen, 2003).

This study uses a multisite study design, namely data analysis that produces detailed descriptions of situations, events, interactions, and key informant behaviors (Jones et al., 2010) from the principal, vice-principal in curriculum, vice principal in student affairs, vice principal in public relations, deputy head of school in the field of infrastructure, head of department, education staff, head of the student council at SMKN 1 Tanjung and SMKN 1 Murung Pudak. According to Bogdan and Toylor (Moleong, 2000: 3), it is defined as a research procedure that produces descriptive data in the form of words both written and oral forms of the actors being observed.

According to Moleong (1991) states there are ten characteristics of qualitative research, namely (1) natural background, (2), humans, 
as instruments (3) qualitative methods (4) inductive data analysis (5) descriptive basic theory (6) Concerned with the process compared to the results (7) the limits are determined by the focus of the research, (8) there are special criteria for the validity of the data, (9) The design is made provisional and the results are mutually agreed.

According to Arikunto (1992) in general, descriptive research is non-hypothesis research, so that the research does not need to formulate a hypothesis. According to Huberman \& Miles (2014), qualitative research data analysts are research that can be truly convincing. Qualitative data analysis is an ongoing, iterative, and continuous effort. Reducing the data, presenting the data, and concluding/verifications to illustrate success in a sequence as a series of successive analysis activities.

\section{Single-site and data analysis}

Single site data analysis is an individualized assessment that leads to a further research process. Assessment of data on the site was carried out on each research subject, namely SMKN 1 Tanjung and SMKN Murung Pudak. This analysis was carried out while collecting data. Once collected, the data analysis flow on the site is as follows.

\section{Data reduction}

Data reduction is the activity of purifying, classifying, directing, removing unnecessary and coordinating data in such a way that conclusions are obtained and verified. During data collection, the reduction has been done, then summarized, and grouped according to the classification of themes.

\section{Presentation of data}

The presentation of data is intended to find meaningful patterns and provide the possibility of concluding. In research in the form of paragraph arrangement, the data presentation is done in narrative form (Murray, 2018) with the help of matrices, graphs, networks, and charts. Data will be presented on the implementation of partnership management.
Techniques that can be used to verify are triangulation of method sources (Yeasmin \& Rahman, 2012), peer discussions, and consultation with supervisors. For more details, the analysis model that the researcher will use in this qualitative research is the interactive data analysis model of Huberman and Miles (2014). For more details, please see the picture of the simultaneous cycle process below:

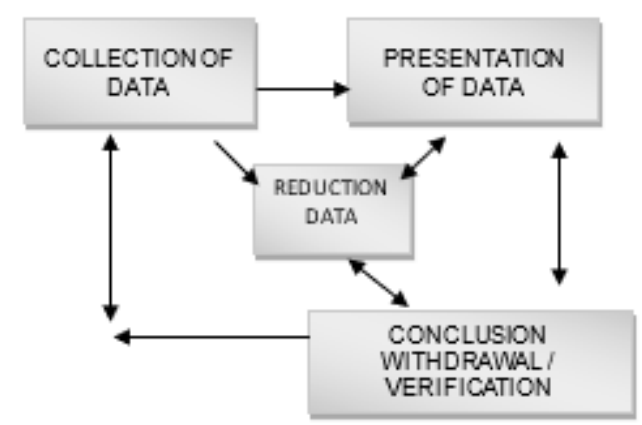

Figure 1. Data analysis technique (adopted miles huberman data technique)

\section{Results and Discussion}

Based on the findings obtained for school partnership management planning, organizing, implementing, and evaluating can be explained as follows:

\section{Research findings}

Based on data found in two locations of each school, namely at SMKN 1 Tanjung as the first site, and SMKN 1 Murung Pudak on the second site regarding school partnership management to improve the quality of education (Ayeni, 2012) with data obtained by researchers through observation, interviews, and documentation obtained by the researcher in the field, the researcher proposes the following propositions;

\section{School partnership management to improve education quality at SMKN 1 Tanjung, Taba- long Regency.}

a) Planning for school partnerships in improving the quality of education at SMKN 1 Murung Pudak, Manajenem Partnership for schools at SMKN 1 Murung Pudak as follows; 
(1) There is a school partnership foundation with $\mathrm{Du} / \mathrm{Di}$ based on the vision and mission of the school that has been set by SMKN 1 Tanjung. (2) Having a partnership objective, either the school or the school partner. (3) There is good communication, especially from schools to school partners, as well as Du / Di to the school.

(4) The school must be able to give trust to Du / Di in a good school condition and by always maintaining the quality of students who are sent as an internship to Du / Di. (5) Relationship with Du / Di begins by adjusting to the state of the department at school. (6) The implementation of education and training for teachers in the Industrial World, to improve teacher competence at SMKN 1 Tanjung. (7) Adjustment of facilities and infrastructure prepared by the school. (8) There is a synchronization of the curriculum.

b) Organizing school partnerships in improving the quality of education (Armstrong, 2015) at SMKN 1 Tanjung includes; (1) Within the school organization and team, from the principal, public relations assistant, internship coordination, coordination of the Special Job Fair and the head of the department and teachers, who become the coordinator of the partnership team lies at the PR office. (2) In establishing partnerships, schools collaborate with government agencies, such as the Department of Manpower and the Office of Education.

c) Implementation of school partnerships in improving the quality of education at SMKN 1 Tanjung the activities carried out are as follows; (1) The implementation of precancerous activities in the Industrial World is carried out in class (Lasse, 2019) XI students in semesters 3 and 4 . (2) There is a partnership agreement with as many as $80 \mathrm{Du} / \mathrm{Di}$ (3) The cooperation agreed with school partners with Du / Di includes synchronizing the curriculum (4) The presence of guest teachers or industrial visits to schools (5) The implementation of teacher training to the Industrial World (6) The signing of the agreement.

d) Evaluation of school partnerships in improving the quality of education in SMK 1 Tanjung standardized from Du / Di includes; (1) The limited funds owned by the school in fulfilling the tools as a means for students to practice, therefore by partnering this can be overcome (2) There needs to be good two-way communication, through a meeting of student guardians to find solutions to what is the problem in school (3) The advantages felt by the school with this school partnership, students are allowed to practice directly in the industrial world as if in the real world of work (Flynn et al., 2016). The advantage for school partners is that the business world can play a role in implementing the revitalization of SMK. (4) No losses were found, either the school or the Du / Di.

\section{School partnership management to improve education quality at SMKN 1 Murung Pudak Tabalong}

a) School partnership planning in improving the quality of education at SMKN 1 Murung Pudak is as follows: (1) The foundation of the school partnership relationship with $\mathrm{Du} / \mathrm{Di}$ based on the school's vision and mission that has been set by SMKN 1 Murung Pudak. (2) The description of the vision and mission of the school is managed by each department and then coordinated by the Deputy Public Relations as a school partnership team (3) Has a partnership objective of either the school or the school partner. (4) 
There is always active and good communication, especially from schools to school partners, as well as Du / Di to the school. (5) The school always gives trust to the school partners in the good condition of the school partners (6) There is a synchronization of the curriculum.

b) Organizing school partnerships in improving the quality of education at SMKN 1 Murung Pudak, the activities include; (1) Within the school's organization and team, from the school principal, public relations assistant, internship coordination, coordination of the Special Job Exchange and the head of the Department at SMKN 1 Murung Pudak (2) School partnerships with $70 \mathrm{Du} / \mathrm{Di}$ collaborate with government agencies, such as the Office Labor, education service.

c) Implementation of school partnerships in improving the quality of education at SMKN 1 Murung Pudak, the activities carried out are as follows; (1) The implementation of industrial work practices to the Industrial World is carried out on grade XI semester 4 students. (2) The existence of a partnership agreement with as many as $70 \mathrm{Du} / \mathrm{Di}$ is proven by the list of $\mathrm{Du} / \mathrm{Di}$ names in the school. (3) There is a synchronization of the curriculum between the business world and the industrial world (4) The presence of guest teachers or industrial visits to SMKN 1 Murung Pudak (5) Teacher training in the Industrial World is carried out (6) Signing of agreements or MoUs with school partners.

d) Evaluation of school partnerships in improving the quality of education in SMKN 1 Murung Pudak standardized from Du / Di includes; (1) The limited budget that schools have for practicing students, therefore by partnering, this can be overcome. (2) There needs to be good two-way communication, through a meeting of student guardian meetings to find solutions to what are the problems at school (3) The benefits felt by schools with this school partnership, students are allowed to practice directly in the industrial world as if in the real world of work. Benefits for school partners, business world the industrial world seems to be the real world of work. Benefits for school partners, the business world can play a role in implementing the revitalization of SMK (4) No losses were found, both the school and the Du / Di.

\section{Proposition}

SMKN 1 Tanjung Tabalong District

a) Planning before forming a team, designing a vision, mission, school motto, and goals, preparing a partnership teamwork program.

b) Carry out the organization by giving additional assignments to competent teachers by forming a partnership team and implementing an annual school partnership program.

c) Implementation of the program the school partnership team for the annual work program, the school always maintains good communication in all directions, not only with school partners but also with parents of students. Curriculum synchronization is very helpful and beneficial for the school. Du / Di's visit to the school, there were guest teachers and internships in the industrial world.

d) Evaluate and supervise every school partnership program that has been implemented, there is an increase in school performance due to an increase in the quality of education. If these obstacles exist, the team that is supported by the principal, the deputy head, and all school members, the school will sit together to find the best solution. Neither the school nor 
the school partners experienced a loss but were equally profitable.

\section{SMK 1 Murung Pudak Tabalong District}

a) Planning the teamwork program, designing the vision, mission, motto, and school goals. In each year, the formation of the school partnership team is always changed, given the backgrounds of the students who each year have various characters. Then plan the school partnership team's annual work program.

b) A clear organization with additional tasks given to teachers by the principal to develop work programs, especially synchronization of the curriculum to improve the quality of education can be achieved.

c) The implementation of the school partnership work program always changes every year, there is always openness and good communication, not only with school partners but also with school members and parents. The existence of a synchronization of the curriculum is very helpful and beneficial to the school.

d) In the implementation of the evaluation, the team must be sensitive to the obstacles found and be able to solve them by finding the best solution by discussing fellow teams and being strongly supported by the principal, vice-principal, and school residents, so that the benefits of both parties, both school, and school partners, do not suffer losses.

\section{Data analysis}

Based on the findings of two cases, namely at SMKN 1 Tanjung and SMKN 1 Murung Pudak, cross-case findings (Gerring, 2007) can be compiled which are grouped into four things that are related to one another, namely; (1) Planning (2) Organizing (3) Implementation and (4) Evaluating the management of school partnerships in improving the quality of education in SMK.

Cross-case findings from two cases, namely at SMKN 1 Tanjung and SMKN 1 Murung Pudak, namely:

\section{Single site data analysis}

a. Single site data analysis at SMKN 1 Tanjung

(1) School Partnership management planning in improving the quality of education at SMKN 1 Tanjung (2) There is a school partnership foundation with $\mathrm{Du} / \mathrm{Di}$ based on the school's vision and mission that has been set by SMKN 1 Tanjung. (3) Has a good partnership objective of the school or school partners. (4) There is good communication, especially from schools to school partners, as well as Du / Di to the school. (5) Schools must be able to give trust to $\mathrm{Du} / \mathrm{In}$ a good school condition and by always maintaining the quality of students who are sent as an internship to Du / Di. (6) Relationship with Du / Di begins by adjusting to the state of the department at school. (7) The implementation of education and training for teachers in the Industrial World, to improve teacher competence (The Australian Industry Group , 2017) at SMKN 1 Tanjung. (8) Adjustment of facilities and infrastructure prepared by schools. (9) Synchronization of the curriculum.

- Organizing school partnership management in improving the quality of education at SMKN 1 Tanjung includes;

In school organizations and teams, from the principal, public relations assistant, internship coordination, coordination of the Special Job Exchange and the head of the department and teachers (Purnamawati, 2018). (2) In establishing partnerships, schools collaborate with government agencies, such as the Manpower Office, the Education Office. 
- Implementation of school partnerships in improving the quality of education at SMKN 1 Tanjung the activities carried out are as follows;

The implementation of industrial work practices to the Industrial World is carried out on students of class XI semesters 3 and 4 (2) There is a partnership agreement with as many as 80 $\mathrm{Du} / \mathrm{Di}$ (3) Collaboration agreed with school partners with $\mathrm{Du} / \mathrm{Di}$ includes curriculum synchronization (4) The presence of guest teachers or industrial visits to schools (5) The implementation of teacher training to the industrial world (6) The signing of the agreement.

- Evaluation of school partnership management in improving the quality of education in SMK 1 Tanjung is standardized from Du / Di includes;

(1) The limited funds owned by the school in fulfilling the tools as a means for students to practice, therefore by partnering this can be overcome (2) There needs to be good two-way communication, through a meeting of student guardian meetings to find solutions to what is the problem in school (3) The benefits felt by the school with this school partnership, students are allowed to practice directly in the industrial world (Gill et al., 2000). Benefits for school partners, the business world can play a role in implementing the revitalization of SMK (4) There are no losses, either the school or the Du / Di.

\section{Discussion}

Discussion of findings referring to the themes produced from all research focuses, namely (1) Planning for school partnerships to improve the quality of vocational educa- tion (2) Organizing school partnerships to improve the quality of education (3) Implementing school partnerships to improve education quality and (4) Evaluating school partnerships the quality of education that must be carried out by the school community.

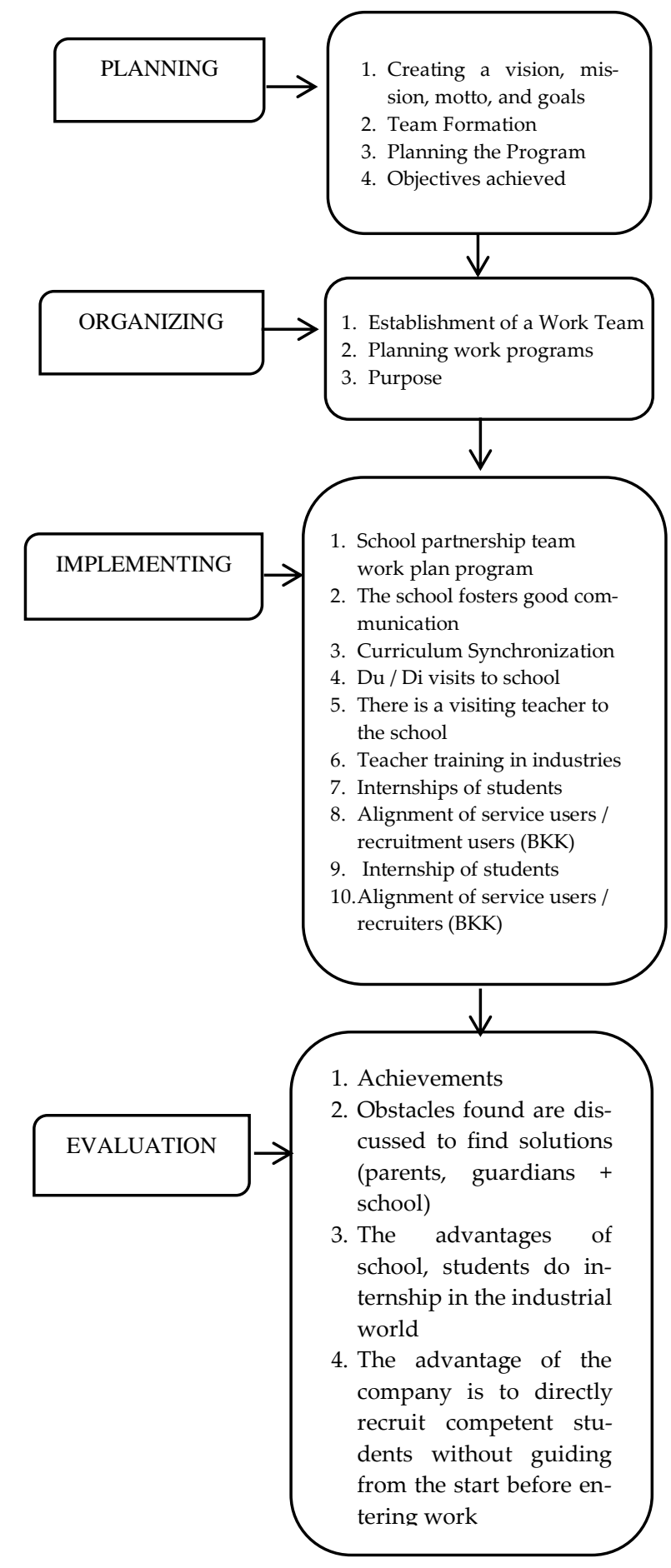

Figure 2. School partnership chart 


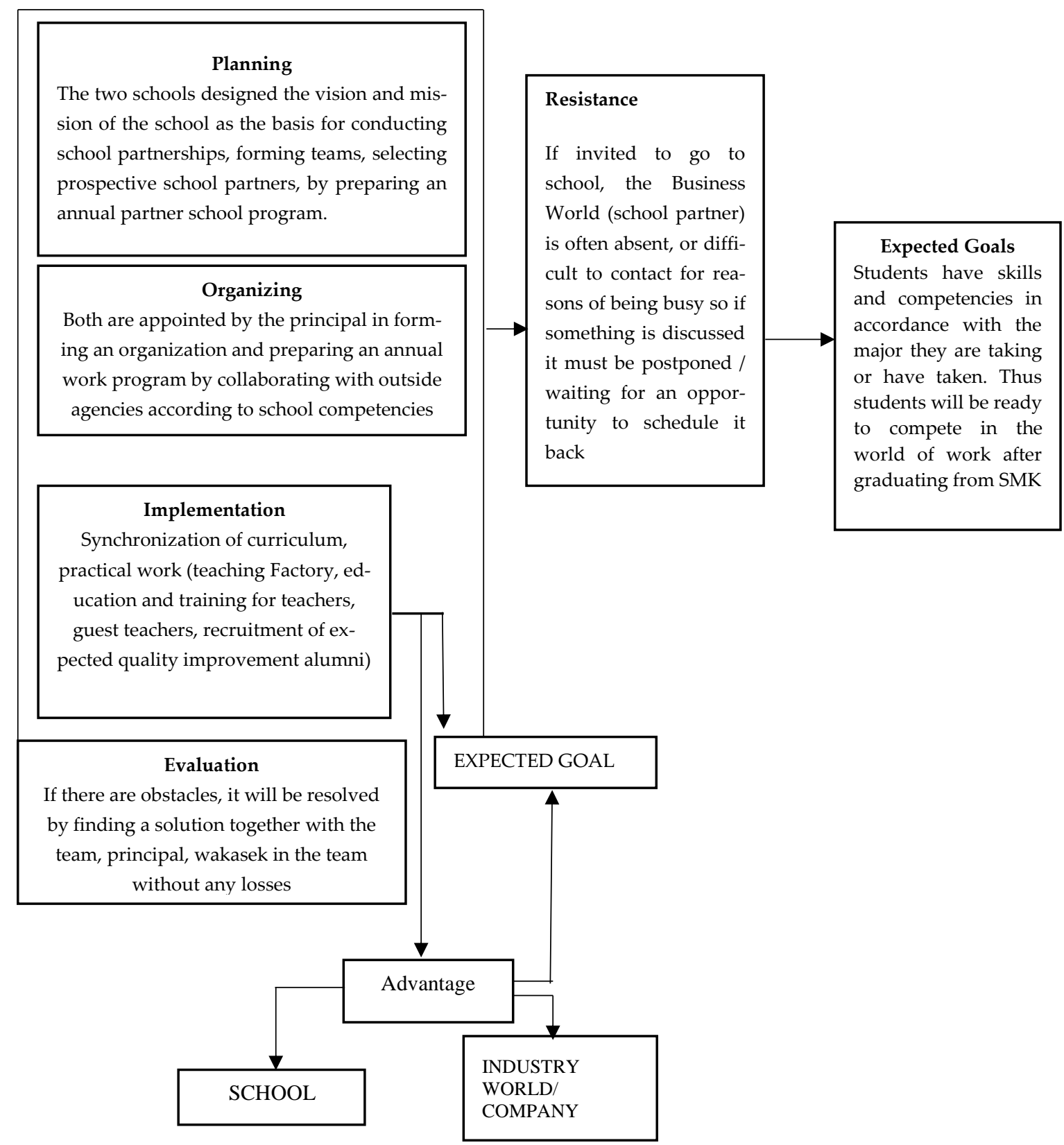

Figure 3. Inter-site features /charts

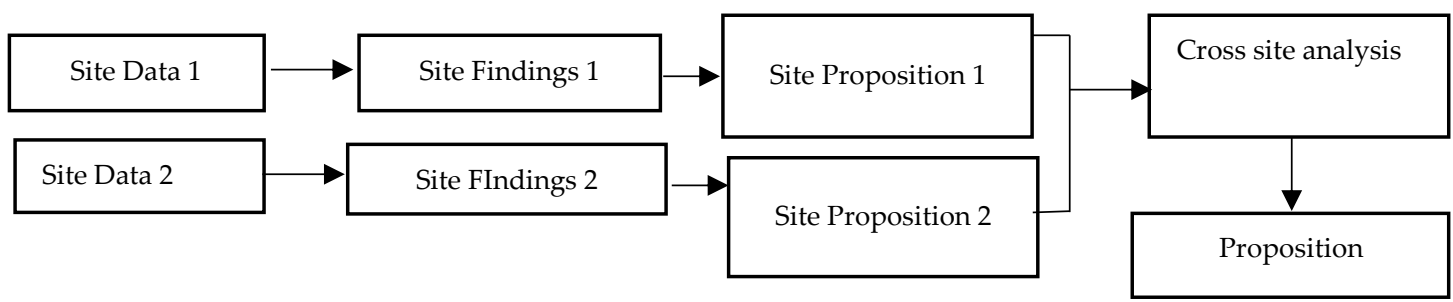

Figure 4. Conceptual framework 


\section{Research result}

From the results of the research based on the comparison table, it can be seen that in principle the two educational institutions, namely SMKN 1 Tanjung and SMKN 1 Murung Pudak, have the same pattern. Both planning, organizing, implementing, and evaluating the management of this school partnership. The differences in several things specifically in planning, implementation, and organization in the two schools, both SMKN Tanjung and SMKN 1 Murung Pudak, namely:

a. The similarities between the two findings are as follows;

- In terms of planning, the two schools designed the vision and mission of the school as the basis for conducting school partnerships, fostering good communication between schools and the business world and industry by preparing programs with the concept of mutual trust towards parties that are school partners.

- In organizing, both are appointed by the principal in forming an organization and preparing an annual work program by cooperating with outside insurers following the competencies the school has.

- In the implementation, both have similarities with curriculum synchronization (Finch \& Crunkilton , 1999) to the business world and the industrial world, there is the internship for students, education and training for teachers who are invited by the industrial world to balance learning in school according to existing competencies in the school, there is the recruitment of alumni from the two schools as employees in the business world as school partners. There is an increase in the quality of education in each school.

- In terms of evaluation, any obstacles will be resolved by finding solutions together. and there is no loss because either the school or the school partner benefit. b. The differences between the two findings are as follows;

- In planning the difference lies in the vision and mission of the school. Then the difference lies in the socialization work program. Where SMKN 1 Tanjung is more focused and active in the business world and the business world tends to wait. Meanwhile, the SMKN 1 Murung Pudak, in addition to schools that are actively involved in the business world, the business world also plays an active role with schools in the socialization process of this partnership.

- In organizing, there is almost no difference where the principal acts as the front command that directs and assigns wakasek, kajur and teachers.

- In terms of implementing school partnerships, principals globally entrust the school partnership team to implement and plan it through team meetings and continue to be supported by all school members, however at SMKN 1 Murung Pudak, they first accept proposals from each Head of the Department before submitted to the school partnership team to discuss together and strongly supported by the principal, wakasek and the school partnership team. This is evident from the data obtained during interviews at the two schools. And in the implementation of the school partnership program, in one of the majors at SMKN 1 Murung Pudak, it was involved in a third-party partner school which was implemented and requested by the first school partner in the TKR department. Because they have to bring in people who are truly competent in the TKR stance. However, it was the first school partner who paid for and supervised the school but it was implemented at SMKN 1 Murung Pudak. Internships and schools only undergo and follow the guidance and training following 
the partnership work program planning that has been mutually agreed upon. Then the teacher training to a different industrial world and guest teachers who teach in schools each month are adjusted according to the competencies or majors in their respective schools. The difference in the implementation of the partnership was also seen in SMKN 1 Murung Pudak where DuDi Mapping was carried out, (1) Capturing Job Fair info (2) Following up on Stock Exchange info (3) distributing alumni search questionnaires (4) Job seeker data entry (3) Job seeker placement. At SMKN 1 Tanjung, alumni have groups and if there are jobs, alumni are only offered. If they are already working even though they are not following their competency background, alumni are considered to have had a job, even though the school directs them to the job field according to their competency background.

Evaluating the differences lies in the obstacles found and the solutions faced by each school.

\section{Conclusion and Recommendation Conclusion}

Based on the research focus, the data obtained, findings and discussions across sites, school partnership management at SMKN 1 Tanjung and SMKN 1 Murung Pudak, from planning, organizing, implementing, and evaluating, this research can be concluded as follows;

This partnership planning is carried out in several ways, namely: Based on the vision and mission of the school, the establishment of partnership goals, forming a school partnership team, compiling a school partnership work program.

Organizing school partnerships in improving the quality of education. Efforts to improve the quality of education at SMKN 1 Tanjung and SMKN 1 Murung Pudak by preparing school partnerships with business and industry in the following ways: the principal appoints several teachers who have the ability by giving additional tasks related to school partnerships, to form a team school partnership work. Then the team prepared a work program.

The school partnership program is implemented by preparing a partnership work program. In the team, there is always openness and good communication with the school community, parents, and school partners. There is a synchronization of the curriculum to match the needs of the curriculum, with teacher education and training to industrial locations and the presence of visiting teachers to schools. Internships carry out direct practice at locations in the business world and in the industrial world so that students experience firsthand as if they are in the real world of work. This is following the Teaching Factory program. Recruitment of competent and unemployed students or apprenticeship in the world of work that requires a new workforce without having to foster and train from scratch,

The school partnership evaluation is carried out if obstacles are found, a team that has been formed will look for solutions, with the strong support of the School Principal, Deputy Principal, Head of the Department, school residents. An increase in school performance is one of the impacts of improving the quality of schools, competent internships will be recruited by the business world and the industrial world where they practice, the advantage is that the business world does not need to foster or educate from the start, so this is time for industrial work practices to begin to enter work, can go straight to work.

\section{Recommendations}

Based on the research results, the suggestions that need to be conveyed by the researcher are as follows:

- For schools

Institutions in the research location, namely SMKN 1 Tanjung and SMKN 1 Murung Pudak, should always maintain various archives and supporting documents related to the partnership. 
- For the principal

The principal is the managerial of an institution, and the person who is very responsible for the success of an institution in the education process and the learning process in schools. Deputy principals, department heads and subject teachers are the supporting elements whose function is to assist the principal and carry out his duties.

- For Teachers

The teacher is the driving force and the most important component in the learning process. The teacher is also the most important factor and very influential. Teachers not only provide knowledge but also provide examples for students, and it is very important with the competence and professionalism of teachers in educating, teaching, and guiding students.

- For the School Committee

The implementation of school partnership management will not take place following the work program properly if it is not accompanied by support from the school committee.

- For the next researcher

To the next researchers, if they do more research, it is hoped that they can enrich and describe the results of the data obtained by describing more constructively comprehensively, and in more detail regarding school partnership management.

\section{Acknowledgment}

The authors are grateful to Universitas Lambung Mangkurat for supporting this research.

\section{References}

Ajayi, V. O. (2017). Primary sources of data and secondary sources of data. Presentation.

Arikunto, S. (1992). Pengelolaan kelas dan siswa. Jakarta Utara: CV Rajawali.

Armstrong, P. (2015). Effective school partnerships and collaboration for school improvement: A review of the evidence. Research Report, Department for Education.

Audet, J., \& d'Amboise, G. (2001). The Multi-site study: An innovative research methodology. The Qualitative Report, 6(2), 1-10.

Ayeni, A. J. (2012). Improving school and community partnership for sustainable quality assurance in secondary schools in Nigeria. International Journal of Research Studies in Education, 1(2), 95-102.

Baral, U. (2017). Research data in social science methods. Journal of Political Science, 17(82).

Bogdan, R., \& Biklen, S. (2003). Qualitative reaseach for education ; And introduction to theory and metods. Boston: Allin and Bacon. Inc.

Denzin, N., \& Lincoln, Y. (2011). Handbook of qualitative research (4th ed.). (Y. Lincoln, Ed.) Thousand Oak, CA: Sage.

Elgar, E. (2012). Public private partnerships in education: new actors and modes of governancein a globalizing world. (S. L. Robertson, K. Mundy, A. Verger, \& F. Menashy, Eds.) Cheltenham, UK: Edward Elgar Publishing Limited.

Finch, C., \& Crunkilton, J. (1999). Curriculum development in vocational and technical education: Planning, content, and implementation. Needham Heights, MA: Allyn\& Bacon Co.

Flynn, M., Pillay, H. K., \& Watters, J. J. (2016). Industry-school partnerships: a strategy to enhance education and training opportunities. Queensland University of Technology.

Gerring, J. (2007). Case study research: principles and practices. Cambridge, UK: Cambridge University Press.

Gill, I., Fluitman, F., \& Dar, A. (2000). Vocational education and training reform, matching skills to markets and budgets. Washington: Oxford University Press.

Greenbank, P. (2014). Preparing students for the graduate labour market: from 'unfreezing' to 'action'. Research in Post-Compulsory Education Conference. University of Oxford.

Hippach-Schneider, U., Schneider, V., Ménard, B., \& TritscherArchan, S. (2017). The underestimated relevance and value of vocational education in tertiary education making the invisible visible. Journal of Vocational Education \& Training, 69(1), 28-46.

Huberman, A., \& Miles, N. (2014). Analisis data kualitatif. Jakarta: Uiversitas Indonesia (UI-Press).

Jones, E., Murphy , A. D., Perez-Vargas, I., Perilla, J., \& Norris, F. H. (2010). Design for data quality in a multisite crosssectional and panel study. Field Methods, 22(3), 250-269.

Kawulich, B. (2005). Participant observation as a data collection method. Forum Qualitative Sozialforschung / Forum: Qualitative Social Research, 6(2), 43.

Mantja. (2008). Profesionalisme tenaga kependidikan dan supervisi pengajaran. Malang: Elang Emas.

Mogalakwe, M. (2006). The use of documentary research methodsin social research. African Sociological Review, 10(1), 221-230.

Murray, M. (2018). Narrative data. in sage, sage handbook of qualitative data collection (U. Flick ed., pp. 264-279). London: Sage. 
OECD. (2017). In-Depth Analysis of the Labour Market Relevance and Outcomes of Higher Education Systems: Analytical Framework and Country Practices Report, Enhancing Higher Education System Performance,. Paris: OECD.

Purnamawati. (2018). A design of partnership model of vocational high school with business and industrial world. International Conference on Indonesian Technical Vocational Education and Association (APTEKINDO 2018). Makassar.

Qaddo, M. (2019). Participant observation as research methodology: Assessing the validity of qualitative observational data as research tools. project.

Rashid, N., Alias, H., Nohuddin, P. N., Hamzah, I., \& Nordin, A. I. (2017). Using data mining strategy in qualitative research. International Visual Informatics Conference.

Sanders, M., Sheldon, s., \& Epstein, J. (2005). Improving school, family, and community partnerships in urban middle schools. Journal of Educational Research \& Policy Studies, 5(1), 24-47.

Sandika, I. B., P.H, S., \& Usman, H. (2017). Partnership model of vocational education with the business sector in civil engineering expertise program of vocational secondary schools . Jurnal Pendidikan Vokasi, 7(3), 247-261.

Satori, \& Komariah. (2009). Metodologi kualitatif. Bandung: Alfabeta.

Shrestha, B. (2016). Vocational education and training graduates: Challenges in practical skills to the job market. International Journal of Social Sciences and Management, 3(3), 141-145.

Simons, M., Lundahl, L., \& Serpieri, R. (2013). The governing of education in Europe: commercial actors, partnerships and strategies. European Educational Research Journal, 12(4), 416-424. 